\title{
AMELIORATIVE RACIAL CLASSIFICATIONS UNDER THE EQUAL PROTECTION CLAUSE: DEFUNIS v. ODEGAARD
}

Assume that an unsuccessful white applicant to a state university discovers that black candidates with lower test scores and grades are being accepted for the entering class for which he has been rejected. He brings suit against the university alleging a denial of equal protection contending that he was denied admission solely because of his race. ${ }^{1}$

This hypothetical situation, posed in March, 1971, became a reahty five months later when Marco DeFunis, Jr., filed suit against Charles Odegaard, the president of the University of Washington. The University's law school had offered seats in the 1971 entering class to thirty-six minority applicants ${ }^{2}$ whose test scores and grades were lower than DeFunis' while DeFunis was denied admission. The subsequent litigation ${ }^{3}$ and appeal ${ }^{4}$ of DeFunis' case has now brought this equal protection issue to the United States Supreme Court, and its decision will assuredly affect all areas of contenuporary race relations. ${ }^{5}$

1. O'Neil, Preferential Admissions: Equalizing Access of Minority Groups to Higher Education, 80 YALE L.J. 699, 706 (1971) (citation omitted).

HEREINAFTER THE FOLLOWING CITATIONS WILL BE USED IN THIS NOTE:

Andersen, The Admissions Process in Litigation, 15 ARIz. L. REV. 81 (1973) [hereinafter cited as Andersen];

Developments in the Law-Equal Protection, 83 Harv. L. REv. 1065 (1969) [hereinafter cited as Developments].

2. "Mimority" within the context of this case refers to Black Americans, Clicano Americans, American Indians, and Philippine Americans. DeFunis v. Odegaard, 82 Wash. 2d 11, 18 n.3, 507 P.2d 1169, 1174 n.3, cert. granted, 42 U.S.L.W. 3300 (U.S. Nov. 19, 1973) (No. 73-235).

3. DeFunis v. Odegaard, No. 741727 (Super. Ct. Oct. 18, 1971) as cited by Andersen at 81.

4. There is no intermediate appellate court between the superior courts and the state supreme court in the state of Washington. See WASH. CoNST. art. IV, $\$ 1$.

In addition to DeFunis' brief, arguing that the United States Supreme Court should note probable jurisdiction or, in the alternative, grant certiorari, and the law school's brief, which sought the opposite result, an amicus curiae brief was filed by Alexander M. Bickel on behalf of the Anti-Defamation League of B'nai B'rith, asking the Court to hear the case.

5. For a discussion of other areas in which preferential treatment of minorities has been, or could be, practiced, see Kaplan, Equal Justice in an Unequal World: Equality for the Negro-The Problem of Special Treatment, 61 Nw. U.I. REv. 363 (1966); Comment, Constitutionality of the "Benign" Quota, 40 TENN. L. REv. 55 
The issue, precisely defined, is whether a state is permitted, within the narrow confines of the fourteenth amendment, to single out members of formerly oppressed minority groups for special, beneficial treatment in the law school admissions context. ${ }^{6}$ The answer to this question and the implications of that answer will be profoundly affected by the standard which the Supreme Court chooses to apply in reviewing the law school's minority admissions program. DeFunis presents to the Court a racial classification unlike any which it has previously examined. Therefore the first question facing the Court is the similarity of that classification to previously examined racial classifications which have been deemed inherently suspect. The Court's choice of the proper standard of review must be based on this preliminary decision. If the facts presented by DeFunis are significantly different from those of the usual racial discrimination case, it may be that the apphication to those facts of what have become the established legal rules of racial discrimination is mappropriate: in a very real way, the Court would be attempting to force a square peg of facts into an ill-fitting round hole in the structure of the law. The purpose of this Note is to examine the Washington Supreme Court's opinion in DeFunis v. Odegaard to determine whether that court applied the appropriate standard of review to the law school's preferential admissions program, and whether the United States Supreme Court should adopt a similar approach.

\section{Factual Background: Preferential ADMISSION OF MINORITIES}

The Board of Regents of the Umiversity of Washington has the power and the duty to establish entrance requirements for students seeking admission to the University. ${ }^{7}$ This responsibility was delegated to the Dean of the law school, who in turn delegated it to the

(1972); Note, Carter v. Gallagher: From Benign Classification to Reverse Discrimination, 34 U. PITT. L. REv. 130 (1972).

6. The phrases most popularly used to refer to the practice of singling out minority groups for special treatment are "preferential treatment" (or "preferential admissions" in the context of higher education); "ameliorative classification"; "benign classification"; and "reverse discrimination." The first two phrases most accurately describe the purpose of such state action. The last two are not strictly accurate and their use should be avoided because "benign classification" connotes a classification which is detrimental to no one-a false assumption-and "reverse discrimination" connotes the type of invidious discrimination which minority groups have traditionally suffered.

7. WASH. Rev. Code ANN. § 28B.20.130(3) (1970). 
Committee on Admissions and Readmissions. ${ }^{8}$ The basic criteria for selection were set out by the admissions committee in a "Guide for Applicants" which accompanied each application:

In assessing applications, we [begin] by trying to identify applicants who [have] the potential for outstanding performance in law school. We [atteinpt] to select applicants for adinission from that group on the basis of their ability to make significant contributions to law school classes and to the community at large.

We [gauge] the potential for outstanding performance in law scliool not only from the existence of high test scores and grade point averages, but also from careful analysis of recommendations, the quality of work in difficult analytical seminars, courses, and writing programs, the academic standards of the school attended by the applicant, the applicant's graduate work (if any), and the nature of the applicant's employment (if any), simce graduation.

An applicant's ability to inake significant contributions to law school classes and the community at large [is] assessed from such factors as his extracurricular and community activities, employinent, and general background. ${ }^{9}$

Implicit in these criteria, but not specifically mentioned by the committee in its pamphlet, was a university-wide policy which sought to reduce or erase the effects of past segregation and discrimination against disadvantaged ethnic and racial minority groups. ${ }^{10}$ This policy

8. The admissions committee was composed of five faculty members and two students at the time of DeFunis' application but was enlarged on June 7, 1971 to include six faculty members and three students. It was apparently this enlarged committee which made the final decision to reject DeFunis' application. DeFunis v. Odegaard, 82 Wash. 2d 11, 15, 507 P.2d 1169, 1172 (1973).

9. 82 Wash. $2 \mathrm{~d}$ at $16,18,507 \mathrm{P} .2 \mathrm{~d}$ at 1173,1174 . The committee also explained that "[a]n applicant's racial or ethnic background was considered as one factor in our general attempt to convert formal credentials into realistic predictions." $I d$. at 19, 507 P.2d at 1174. This statement raised an important issue not dealt with in this Note, i.e., whether grade point average and standard test scores should be adjusted to account for the culturally-deprived background of disadvautaged applicants. Proponents of such practices claim that disadvantaged applicants are poorly equipped in verbal skills, and that therefore their standard academic credentials are not accurate indicators of their academic ability. Compare Bell, In Defense of Minority Admissions Programs: A Response to Professor Graglia, 119 U. PA. L. Rev. 364, 366-68 (1970) with Jensen, Selection of Minority Students in Higher Education, 1970 U. TOL. L. REv. 403, 440-47.

10. The president of the University testified at trial as to the origin of the policy: More and more it became evident to us that just an open door, as it were, at the poimt of entry to the University, somehow or other seemed insufficient to deal with what was emerging as the greatest internal problem of the United States of America, a problem which obviously could not be resolved without some kind of contribution being made not only by the schools, but obviously, also, by the colleges in the University and the University of Wash- 
was based on the belief that black Americans, Chicano Americans, American Indians, and Philippine Americans still suffered the continuing effects of past discrimination. ${ }^{11}$ An explanation of the law school's method of implementing these admissions criteria and policies will provide the factual framework within which the legal issues were decided. ${ }^{12}$

In 1970-71 the law school received 1601 applications for 150 first year slots. ${ }^{13}$ An initial ranking was made by combining, by formula, each applicant's junior and senior undergraduate grade point average and his or her Law School Admissions Test (LSAT) score to derive a Predicted First Year Average (PFYA). The admissions committee had determined that those applicants with a PFYA of 77 or above had the highest probability of success in their first year. The committee also determined that a PFYA of below 74.5 indicated little chance of getting through. Applicants in this lower group were either summarily rejected or placed aside for further review in the light of some significant subjective indicator appearing on the application. ${ }^{14}$ Applications from minority candidates were never summarily rejected but were always referred to the full committee, regardless of the PFYA. ${ }^{15}$

ington, in particular, given the racial distribution of this state.

$\ldots$

So that was the beginning of a growing awareness that just an open door sheer equality in view of the cultural circumstances that produced something other than equality, was not enough; that some more positive contribution had to be made to the resolution of this problem in American life, and something had to be done by the University of Washington. 82 Wash. 2d at 20, 507 P.2d at 1175 .

11. Asian Americans were not included since the law school could admit substantial numbers of this minority group without varying the standards used for the adnission of white candidates. 82 Wash. $2 \mathrm{~d}$ at $18 \mathrm{n} .3,507$ P.2d at $1174 \mathrm{n} .3$.

12. This Note will not attempt to judge the political or social propriety of the law school's minority admissions program, but will confine itself to the legal issues, i.e., whether a state, if it desires to do so, is constitutionally permitted to implement such a program.

13. The number of apphications had increased from 618 in 1967 for the same number of first-year positions to be filled. DeFunis v. Odegaard, 82 Wash. $2 \mathrm{~d}$ at 15 , 507 P.2d at 1172 .

14. See text accompanying note 9 supra.

15. Applicants who were applying for readmission after having been admitted and then inducted into the armed services had a right to reenter if they reapphied immediately upon completion of their tour of duty. Out of this group, twenty-two persons were admitted with PFYA's lower than DeFunis'.

The records show that of the 1601 applicants, 776 (48\%) had PFYA's below 74; $754(47 \%)$, between 74 and 77 ; and $56(3 \%)$, above 77 . PFYA is not shown for $15(1 \%)$ of the applicants. Letter from William R. Andersen, Of Counsel for the law school, Oct. 8, 1973. 
DeFunis' PFYA was computed at 76.23 , which placed him in the group between the highest (77.0) and the lowest (74.5) cut-off points. ${ }^{16}$ It was this middle group which received the heaviest subjective consideration. The file of each applicant in this group was randomly assigned to a committee member who read its contents and summarized them for the full committee. The summary included an evaluation of both the objective and subjective data and often included comments on any unique personal information contained in the file. ${ }^{17}$ After discussion, the committee voted as to the disposition of each applicant, i.e., to accept him, reject him, or put him on a waiting list. Through this complex and highly subjcctive admissions procedure, DeFunis was assigned to a waiting list ${ }^{18}$ and was ultimately denied admission on August 2, $1971 .^{10}$

16. DeFunis graduated from the University of Washington in 1970 with a juniorsenior grade point average of 3.71/4.00. He was denied adunission to the 1970 entering law school class, so he undertook twenty-two hours of graduate work for a grade point average of 3.86. The latter grades were not figured into his PFYA.

Due to his rejection in 1970 , and to his continued interest in law school, DeFunis, by the time he reapplied for the 1971 entering class, had taken the ISAT three times, scoring successively 512, 566 and 668. Pursuant to the law school's admissions policy, the average score, not the highest, was used to determine DeFunis' PFYA of 76.23. The policy was based on the finding that repeated taking of the LSAT has an educatioual effect which allows the apphicant to achieve successively higher scores, to a certain point.

17. Two examples of these summaries are:

Excellent recommendations, sound record. Divorced with five kids. Could make it if her personal situation could be worked out, hightened load possibility? Admit.

... Overall GPA 2.85. [S]trange recommend[ations, e.g.,] "arrogant, conceited" but appareutly bright .... Take a chance on his screwy personality \& admit. 82 Wash. 2d at 57,507 P.2d at 1195 (Hale, C.J., dissenting).

Chief Justice Hale was especially critical of this method of evaluating the applicants. He pointed out that the student members were not specially qualified to inake admissions judgments, and that some of their judgments were apparently founded on a sympathy for those applicants engaged in "activist" community work. Id. at 52-59, 507 P.2d at 1193-96. Moreover, the evaluation seenied to follow no logical pattern and an examination of the files "fails to show any consistent policy on admissions at which a prelaw student could aim his career." Id. at 59, 507 P.2d at 1196.

18. The admissions committee also ranked those candidates assigned to the waiting list into four groups of roughly equal size. DeFunis-with thirty-two otherswas ranked in the bottom quartile, the group least likely to receive offers of admission.

19. Of nine apphicants with a PFYA of 76.23, two were granted admission. Andersen at 84.

Along with this rejection, however, DeFunis could count his four acceptances from the law schools at the University of Oregon, the University of Idaho, Gonzaga University, and Willamette University. 82 Wash. $2 d$ at 30 n.11, 507 P.2d at 1181 n.11. 
Minority applicants were accorded different treatment, however. Their files were always assigned to particular members of the admissions committee: applications from black Americans were committed to a faculty member who had prior experience in minority admissions $^{20}$ and to a black student committee member; applications from other minority candidates were initially reviewed by an associate dean who later presented his findings to the full adinissions committee. ${ }^{21}$ For its part, the committee compared each minority candidate with other minority applicants-not with non-minority candidates-and in general sought those minority applicants whom it believed would be capable of completing the law school program. If the committee felt that a minority applicant could get through the first year, that applicant was offered admission. ${ }^{22}$

The major result of the admissions procedure-at least from DeFunis' viewpoint-was that he, with a PFYA of 76.23, was not admitted, while some thirty-six minority applicants with lower PFYA's were offered seats in the entering class. ${ }^{23}$

In August, shortly after receiving his rejection letter, DeFunis filed suit in the superior court of King County, Washington, against almost everyone who miglit have been connected with the adinissions process. ${ }^{24}$ The complaint alleged three general causes of action ${ }^{25}$

20. Professor Geoffrey Crooks was the 1970 summer director of the law school's Council of Legal Education Opportunities (CLEO) program, a federally funded program sponsored by the American Bar Associatiou, the American Association of Law Schools, the National Bar Association, and the Law School Admissions Council, which provides summer training and financial aid to disadvantaged college students seeking admissiou into a law school. 82 Wash. $2 d$ at 19 n.4, 507 P.2d at 1175 n.4. For a report on the experience of some of these summer programs, see Symposium: Disadvantaged Students and Legal Education-Programs for Affirmative Action, 1970 U. ToL. L. Rev. 277, 633-808.

21. 82 Wash. 2d at 19, 507 P.2d at 1175 .

22. It is crucial to remember that minority applicants who were admitted were certainly qualified in the absolute sense, but were less qualified than some nonminority candidates when judged by traditional academic standards.

23. One-half of the thirty-six minority admittees actually enrolled in the firstyear class. Twenty-nine other applicants in DeFunis' situation were similarly denied admission. The highest PFYA of the 1971 entering class was 80.01; the median PFYA was 76.61. Letter from William R. Andersen, Of Counsel for the law school, Oct. 8, 1973.

24. The parties defeudant included the board of regents, the president, the registrar of the university, the dean of the law school, and two faculty inembers of the admissions committee. Andersen at 85 n.5.

25. They were: (1) the law school had admitted many candidates whose PFYA's were lower than DeFunis'; (2) the law school had unjustly discriminated against resident taxpayers by accepting non-taxpaying non-residents; and (3) the law school had given DeFunis misleading advice concerning his attempt to gain admission. Id. at 
and prayed for an order that the defendants admit and enroll DeFunis in the law school in the fall of $1971 .^{28}$ DeFunis argued that he had been denied the equal protection of the laws because the law school had used race as an admissions criterion. Defendants responded that the use of race in structuring the admissions classifications was done in the pursuit of legitimate state purpose-i.e., improving the quality of the educational process and increasing the nuniber of ninorities in the legal profession-and therefore did not violate the fourteenth amendnent. ${ }^{27}$ A brief survey of conteinporary fourteenth amendment jurisprudence is necessary for a clear understanding of the state supreme court's decision on this issue.

\section{Legal Background: The Two Levels of Review}

The fourteenth amendment provides in part: "No state shall . . . deny to any person within its jurisdiction the equal protection of the laws." The judicial construction of this constitutional mandate has centered on an examination of the ways in which persons are classified by the state. ${ }^{28}$ The Supreme Court has decided, and repeatedly affirmed, that when a state treats persons unequally because of their race, ${ }^{20}$ national origin, ${ }^{30}$ or alienage, ${ }^{31}$ these classifications are constitutionally

85-86. The first cause of action was stated in general terms and did not specifically allege that the minority admissions program was responsible for the acceptance of less qualified applicants and the rejection of DeFunis. This subject was first broached during discovery, see id. at 88 , and the equal protection issue was not presented to the trial court until after the trial was in progress. $I d$. at 89 .

26. 82 Wash. $2 \mathrm{~d}$ at $13,507 \mathrm{P} .2 \mathrm{~d}$ at 1172 . DeFunis asked in the alternative that he recover $\$ 50,000$ in damages allegedly caused by the projected increased living expenses in au out-of-state law school, the loss of his wife's income for the three years of law school, and the inherent handicaps he would face in an expected law practice in Washimgton because he was not trained in the state. Andersen at 85 n.10. Early in the proceedings the trial court dismissed this claim for money damages. 82 Wash. $2 \mathrm{~d}$ at $14,507 \mathrm{P} .2 \mathrm{~d}$ at 1172.

27. Andersen at 89.

28. A classification may be explicit, see Morey v. Doud, 354 U.S. 457 (1957); implicit, see Allied Stores, Inc. v. Bowers, 358 U.S. 522 (1959); or may arise from the enforcement of a statute or ordinance, see Yick Wo v. Hopkins, 118 U.S. 356 (1886).

For a comprehensive survey of equal protection precedent through 1969, see Developments.

29. See, e.g., McLaughlin v. Florida, 379 U.S. 184 (1964); cf. Bolling v. Sharpe, 347 U.S. 497 (1954).

30. See Korematsu v. United States, 323 U.S. 214 (1944); Hirabayashi v. United States, 320 U.S. 81 (1943).

31. See In re Griffiths, 93 S. Ct. 2851 (1973); Sugarman v. Dougall, 93 S. Ct. 2842 (1973); Graham v. Richardson, 403 U.S. 365 (1971); Takahashi v. Fish \& Gaine 
suspect ${ }^{32}$ and must be subjected to close judicial scrutiny. ${ }^{33}$ Unless the Court finds that these suspect classifications are necessary for the accomplishment of some overriding state objective, the classification will be held in violation of the fourteenth amendment equal protection clause. ${ }^{34}$ The burden of justifying the use of a suspect classification is so heavy that no state has ever been able to justify a suspect classification to the satisfaction of the Supreme Court; the federal government has succeeded only twice. ${ }^{35}$ A similarly strict standard of review is applied to classifications which impinge upon "fundamental" rights or interests, which include voting, ${ }^{36}$ procreation, ${ }^{37}$ marriage, ${ }^{38}$ travel, ${ }^{39}$ and fair criminal procedure. ${ }^{40}$ In this situation the Court has required the state to show that the classification is necessary to accoinplish a "compelling state interest," 41 and that less onerous alternatives are unavailable. ${ }^{42}$

The standard developed to examine classifications which are suspect or which infringe upon fundamental interests is commonly called the "higher standard of review" or the "strict scrutiny standard." 43

Comm'n, 334 U.S. 410 (1948). But see Sugarman v. Dougall, 93 S. Ct. 2842, 2861 (1973) (Rehnquist, J., dissenting) (alienage is not a suspect criterion).

32. See, e.g., Graham v. Richardson, 403 U.S. 365, 372 (1971); Bolling v. Sharpe, 347 U.S. 497, 499 (1954).

33. See, e.g., Frontiero v. Richardson, 411 U.S. 677, 688 (1973); Loving v. Virginia, 388 U.S. 1, 11 (1967); Korematsu v. United States, 323 U.S. 214, 216 (1944).

34. See, e.g., In re Griffiths, 93 S. Ct. 2851, 2855 (1973); Loving v. Virginia, 388 U.S. 1, 11 (1967); McLaughlin v. Florida, 379 U.S. 184, 192, 196 (1964); Korematsu v. United States, 323 U.S. 214, 216 (1944).

35. The federal government is bound by the same standard when it classifies people into groups, see Bolling v. Sharpe, 347 U.S. 497, 500 (1954), but it was able to sustain the heavy burden of justification in two cases in which the exigencies of wartime demanded discriminatory treatinent of Japanese-Americans during World War II. See Korematsu v. United States, 323 U.S. 214 (1944) (exclusion froln designated areas); Hirabayashi v. United States, 320 U.S. 81 (1943) (curfew regulations).

36. See, e.g., Dunn v. Blunustein, 405 U.S. 330 (1972).

37. See Skinner v. Oklahoma ex rel. Wilkamson, 316 U.S. 535 (1942).

38. See Loving v. Virginia, 388 U.S. 1 (1967) (classification also based on race, a suspect criterion).

39. See Shapiro v. Thonipson, 394 U.S. 618 (1969).

40. See, e.g., Griffin v. Illinois, 351 U.S. 12 (1956).

41. See Dunn v. Blumstein, 405 U.S. 330, 342 (1972).

42. See id. at 343.

43. Although the Court has required the state to show an "overriding" or "substantial" state purpose to justify classifications which are suspect and has spoken of a "compelling state interest" when fundamental rights were involved, this difference is purely senantic; the Court has required the same showing in either situation. See, e.g., San Antomio Indep. School Dist. v. Rodriguez, 411 U.S. 1, 16-17 (1973); Shapiro v. Thompson, 394 U.S. 618, 634 (1969) (a fundamental-interest decision citing Korematsu, a suspect-classification decision). Moreover, a recent Supreme Court footuote has ratified this implicit understanding: "The state interest required [under the higher 
In reviewing all other state actions which classify people into groups, the Court is inore lenient. ${ }^{44}$ The classifications are accorded a presumption of constitutional validity and the Court requires only that they bear some rational relationship to a legitimate state purpose. ${ }^{45}$ This standard of review has commonly been referred to as the "lower standard of review" or the "rational-basis standard."

With this two-tiered framework of review in mind, but before proceeding to the trial and appeals opinions in DeFunis, it would be appropriate to review the case of Brown $v$. Board of Education, ${ }^{\mathbf{4 0}}$ which figured heavily in these decisions.

Brown, the landinark Supreme Court decision which overruled the "separate but equal" doctrine announced in Plessy v. Ferguson, ${ }^{47}$

standard] has been characterized as 'overriding, 'compelling,' 'important,' or 'substantial.' We attribute no particular significance to these variations in diction." In re Griffiths, 93 S. Ct. 2851, 2855 n.9 (1973) (citations omitted).

44. It was recently stated that these actions might be classified as operating in the area of "economics and social welfare," Dandridge v. Williams, 397 U.S. 471, 485 (1970), but in actuality they include all those classifications which do not involve suspect criteria, or impinge upon fundamental imterests.

45. E.g., Weber v. Aetna Cas. \& Sur. Co., 406 U.S. 164, 172 (1972); Eisenstadt v. Baird, 405 U.S. 438, 446 (1972), quoting Reed v. Reed, 404 U.S. 71, 75-76 (1971). While the standard of review as announced in these recent cases bespeaks a laissezfaire, hands-off approach to most state classifications, this standard is stricter than the one espoused as recently as 1969 when the Court stated that a "statutory discrimination will not be set aside if any state of facts reasonably may be conceived to justify it." Dandridge v. Williams, 397 U.S. 471, 485 (1970), quoting McGowan v. Maryland, 366 U.S. 420,426 (1961). The difference is that the Court will now make a more extensive inquiry to determine whether there actually is a rational relationship between the state's classification and the purpose it hopes to achieve. For a discussion of this recent judicial trend, see Aguayo v. Richardson, 473 F.2d 1090, 1109 (2d Cir. 1973); City of New York v. Richardson, 473 F.2d 923, 931 (2d Cir. 1973); Green v. Waterford Bd. of Educ., 473 F.2d 629, 633 (2d Cir. 1973); Gunther, The Supreme Court, 1971 Term-Forward: In Search of Evolving Doctrine on a Changing Court: A Model for a Newer Equal Protection, 86 HARv. L. REv. 1 (1972); Note, The Decline and Fall of the New Equal Protection: A Polemical Approach, 58 VA. L. REv. 1489 (1972).

46. 347 U.S. 483 (1954).

47. 163 U.S. 537 (1896). The Court in Plessy stated:

Laws permitting, and even requiring [the separation of the races] in places where they are liable to be brought into contact do not necessarily imply the inferiority of either race to the other .... The most common instance of this is connected with the establishment of separate schools for white and colored children .... [W] cannot say that a law which authorizes or even requires the separation of the two races in public conveyances is unreasonable, or more obnoxious to the Fourteenth Amendment than the acts of ... state legislatures [requiring separate schools for the two races] .... If one race be inferior to the other socially, the Constitution of the United States cannot put them upon the sanie plane. Id. at 544, 550-52.

For an excellent survey of the application of Plessy over the years, see Larson, The New Law of Race Relations, 1969 Wisc. L. REv. 470, 482 n.27. 
held that "[s]eparate educational facilities are inherently unequal."48 The Court's decision was based on the finding-which controverted the Court's finding in Plessy ${ }^{49}$ - that

[t]o separate [children in grade and high schools] from others of similar age and qualifications solely because of their race generates a feeling of inferiority as to their status in the community that may affect their hearts and minds in a way unlikely ever to be undone. ${ }^{50}$

This finding was the final $s^{5 t e} p^{51}$ in the judicial recognition of the importance of intangible educational opportunities in the academic and psychological developinent of school children. ${ }^{52}$

A thorough analysis of the Court's opinion, however, reveals the absence of any attempt to apply either the higher or lower standard of equal protection review. ${ }^{53}$ This may have been because, in overruling Plessy, it was simpler for the Court to state its new rule as the antithesis of the Plessy rule: the fourteenth amendment requires that public educational facilities, if provided, be provided to all races equally. The Brown court reasoned that, as long as the races were

48. 347 U.S. at 495.

49. See 163 U.S. at 551.

50. 347 U.S. at 494 . The Court also adopted the finding of the federal district court in Kansas:

Segregation with the sanction of the law ... has a tendency to [retard] the educational and mental developinent of negro children and to deprive them of some of the benefits they would receive in a racial[y] integrated school system. IId.

The source of that quotation is not apparent from either the Supreme Court or federal district court opinion. See id.; Brown v. Board of Educ., 98 F. Supp. 797 (D. Kan. 1951).

51. Earlier cases involving segregated law and graduate school facilities recognized that the inequality of intangible factors, e.g., reputation of the school, and opportunity to discuss ideas with members of the majority race, were enough to support a finding that the Negro plaintiffs were denied equal protection of the laws. See McLaurin v. Oklahoma State Regents, 339 U.S. 637 (1950) (graduate school); Sweatt v. Painter, 339 U.S. 629 (1950) (law school); Missouri ex rel. Gaines v. Canada, 305 U.S. 337 (1938) (law school).

52. See Brown v. Board of Educ., 347 U.S. 483, 494 \& n.11 (1954).

53. See notes 29-45 supra and accompanying text. However, Mr. Chief Justice Warren, in Bolling v. Sharpe, 347 U.S. 497 (1954), the companion case to Brown, employed the strict standard of review to strike down de jure segregation of public schools in the District of Columbia. Holding that classifications based on race are constitutionally suspect and hence must be closely scrutinized, id. at 499, he concluded that "[s]egregation in public education is not reasonably related to any proper governmental objective . . ."Id. at 500. Mr. Chief Justice Warren was the author of both the Brown and Bolling opinions, and one wonders why Brown was not written in terms of the conventional equal protection analysis employed in Bolling. The reason is uot apparent, although it may have been because Brown was confined by the logical framework of Plessy since both cases involved instances of state-imposed segregation; Bolling, on the other hand involved federally-legislated segregation of public schools, and was not therefore bound by the "separate but equal" parametcrs. 
required by law to attend separate schools, equal educational facilities would never be provided to Negro children.

Brown became the seminal case in the field of racial discrimination in public education, ${ }^{54}$ including public higher education. ${ }^{55}$

\section{The Trial Decision and Appeal: Selecting THE PROPER STANDARD}

After a consideration of the testimony ${ }^{56}$ and the arguments, the trial judge ruled that DeFunis had been denied the equal protection of the laws because less qualified minority students were admitted while he was not. ${ }^{57}$ In holding that a state law school could never consider race as an imdependent criterion in its admissions process, the court cited Brown and held that

54. Although petitioner Brown's counsel expressly rejected the idea of wholesale invalidation of state segregation laws in other areas purely on the weight of a decision in that case, see 21 U.S.L.W. 3162 (1952), the Court summarily extended Brown through a series of per curian opinions to strike down segregation on public beaches, Mayor of Baltimore v. Dawson, 350 U.S. 877, aff'g per curiam 220 F.2d 386 (4th Cir. 1955); public golf courses, Holmes v. City of Atlanta, 350 U.S. 879, rev'g per curiam 223 F.2d 93 (5th Cir. 1955); public buses, Gayle v. Browder, 352 U.S. 903, aff'g per curiam 142 F. Supp. 707 (M.D. Ala. 1956); public parks, New Orleans City Park and Improvement Ass'n v. Detiege, 358 U.S. 54, aff'g per curiam 252 F.2d 122 (5th Cir. 1958); aud in the public boxing ring, State Athletic Comm'n v. Dorsey, 359 U.S. 533 (1959), aff'g per curiam 168 F. Supp. 149 (E.D. La. 1958).

55. See, e.g., Pennsylvania v. Board of Directors, 353 U.S. 230 (1957); Florida ex rel. Hawkins v. Board of Control, 350 U.S. 413 (1956) (per curiam).

56. See note 10 supra. The dean of the law school testified that the preferential admissions policy was designed to serve the overall educational mission of the school, and to increase the number of minority lawyers in the profession. In this context the defendants offered testimony regarding the widespread underrepresentation of minorities in the profession, and the concomitant need for increased representation. Andersen at 100 . See note 111 infra.

57. The other issues presented to the trial court, and some of the answers given by the trial judge - the case was tried without a jury-were:

1. What is the appropriate scope of judicial review of an admissions decision? Andersen at 90. (The Washington Supreme Court discussed this issue. DeFunis v. Odegaard, 82 Wash. $2 \mathrm{~d}$ at 25 n.8, 507 P.2d at 1178 n.8.)

2. Is it rational to use LSAT scores at all in cases where the GPA is extremely high? Yes. Andersen at 90, 108.

3. Is it appropriate in computing the LSAT part of the PFYA to average all scores? Yes. Id.

4. Was it proper for the law school to use students on the admissions committee, especially in light of the fact that many of the decisions are at variance with the strict numerical ranking of the applicants? Yes. Id.

5. Was it proper for the admissions committee to use criteria other than the strict numerical ranking of the candidates? Yes. Id. at 96-100, 108 .

6. Are university files and records (except the name of the respective applicant) discoverable? Yes. Id. at 90, 103.04.

7. Does a state-supported school have a legal obligation to grant preference to qualified resident applicauts? No. Id. at 90, 107, 108 .

For the Washington Supreme Court's approach to some of these issues, see note 61 infra. 
[a]fter that decision the 14th amendment could no longer be stretched to accommodate the needs of any race. Policies of discrimination will inevitably lead to reprisals. In my opinion the only safe rule. is to treat all races alike, and I feel that is what is required under the equal protection clause. 58

DeFunis was ordered admitted to the 1971-72 first year class. ${ }^{59}$

On appeal ${ }^{80}$ the Washington Supreme Court reversed, holding

58. DeFunis v. Odegaard, No. 741727 (Super. Ct., Sept. 22, 1971) (oral decision) (reported in Andersen, at 108). The trial judge's entire opinion on the issue is recorded as follows:

It seems to me that the law school here wished to achieve greater minority representation and in accomplishing this gave preference to the members of some races. In doing this the admissions committee assnmed that all meinbers of minority races, with the exception of Asians, were deprived persons. The applications of the Black students were separated from all others and assigned to a Black student and a professor who had worked closely with the CLEO program.

Some minority students were admitted whose college grades and aptitude test scores were so low that had they been whites their applications would have been summarily denied. Excluding the Asians only one minority student out of 31 admitted among the apphicants had a predicted first year average above the plaintiff.

Since no more than 150 applicants were to be admitted the admission of less qualified [applicants] resulted in a denial of places to those otherwise qualified. The plaintiff and others in this group have not in my opinion been accorded the equal protection of the law guaranteed by the 14th amendinent.

In 1954 the United States Supreme Court in Brown v. Board of Education decided that public education must be equally available to all regardless of race.

This decision was immediately criticized by the president of the university, who felt that the trial court had misinterpreted the fourteenth amendment:

It is clear that the main issue in this case turns on the interpretation of the fourteenth amendment .... as it is applicable to the admission of persons from educationally disadvantaged backgrounds to higher education. . . . The fundamental purpose of the university's affirmative action program in admissions is to fulfill the obligation called for by the Fourteenth Amendment by providing equal educational access to all, including those who have been educationally disadvantaged. 57 A.B.A.J. 1234 (1971) (statement made on Sept. 24, 1971).

For other critiques of the trial ruling see Comment, 21 AM. U.L. REv. 736 (1972) (ruling was incorrect); 52 B.U.L. REv. 304 (1972) (ruling was incorrect); 49 CHI.-KENT L. REV. 132 (1972) (ruling has significant precedential support).

59. Andersen at 108. DeFunis had actually already been admitted pursuant to a temporary injunction issued by the trial judge which enjoined defendants from admitting any law students "in a number which would preclude the admission of plaintiff, Marco DeFunis, Jr., to the 1971-72 first year class . . ." 82 Wash. $2 d$ at 14, 23 n.6, 507 P.2d at 1172,1177 n.6.

The law school was faced with a serious dilemma: the specific relief granted was the order requiring that DeFunis be admitted, not that the law school discontinue its mmority admissions program; the clear holding, however, had been that the program was unconstitutional. After much discussion the law school decided to continue the program into the next year, hoping for a reversal in the state supreme court. Andersen at 109-10.

60. Several amicus curiae briefs were filed in support of the minority admissions program, including those of the American Bar Association, the Association of Ameri- 
that the law school's voluntary action in implementing its preferential admissions program did not violate the fourteenth amendment. ${ }^{01}$ Brown and more recent cases, ${ }^{02}$ said the court, do not support the conclusion that considerations of race in implementing an admissions program are per se invalid under the equal protection clause. ${ }^{\circ 3}$ Because race is a suspect classification, however, its use by the admissions committee as one criterion in evaluating applicants must, in hight of clearly established precedent, ${ }^{64}$ be subjected to the higher standard of equal protection review; the law school nnust show that the racial classifications were necessary to further a compelling state interest. ${ }^{65}$ The Court concluded that the law school had shown at least three

can Law Schools, the Law School Admissions Council, and CLEO, jointly; the American Association of University Professors; the American Indian Law Students Association; the Black American Law Students Association and Law Students Civil Rights Research Council, jointly; and the American Civil Liberties Union. Andersen at $112 \mathrm{n} .70$.

61. Regarding sone of the other issues presented, the Washington Supreme Court upheld the adinission coinmittee's use of non-quantitative criteria, 82 Wash. $2 d$ at $38-42$, 507 P.2d at 1185-87; refused to decide whether the LSAT contained an inherent cultural bias, 82 Wash. 2d at 41, 507 P.2d at 1186; and rejected DeFunis' contention that the law school must give admissions preference to Washington residents, 82 Wash. $2 \mathrm{~d}$ at $42-44,507$ P.2d at $1187-8$.

A collateral issue which this Note will not fully develop relates to the scope of the racial classification. "A validly drawn classification is one "which includes all [and only those] persons who are sinularly situated with respect to the purpose of the law." 82 Wash. $2 \mathrm{~d}$ at 36,507 P.2d at 1184, quoting Tussnian \& tenBroek. The Equal Protection of the Laws, 37 CALIF. L. Rev. 341, 346 (1949). The purpose of the classification, the court found, was to give specific consideration to those minority groups which are underrepresented in law school and the profession, and which cannot secure proportionate representation under traditional admissions criteria. In light of this purpose, the state need not include all racial minorities, but could identify and seek to correct the most serious racial imbalances without attempting to provide an immediate solution to the overall problem of equal representation in the legal system. 82 Wash. 2d at 37, 507 P.2d at 1184.

Some commentators disagree with the use of any racial classification to aid the disadvantaged, arguing instead that the beuefits of preferential treatment should be distributed along economic class lines. See Freund, Civil Rights and the Limits of Law, 14 Buffalo I. Rev. 199, 204 (1964); Kaplan, Segregation Litigation and the Schools-Part 1I: The General Northern Problem, 58 Nw. U.L. REv. 157, 207 (1963). See also Kaplan, supra note 5, at 363, 373-74.

62. The court cited North Carolina State Bd. of Educ. v. Swann, 402 U.S. 43 (1971); Swann v. Charlotte-Meckleuburg Bd. of Educ., 402 U.S. 1 (1971); Green v. County School Bd., 391 U.S. 430 (1968); Carter v. Gallagher, 452 F.2d 315 (8th Cir. 1971), cert. denied, 406 U.S. 950 (1972); and Porcelli v. Titus, 431 F.2d 1254 (3d Cir. 1970), cert. denied, 402 U.S. 944 (1971).

63. 82 Wash. $2 \mathrm{~d}$ at 31,507 P.2d at 1181. See notes 71-89 infra and accompanying text.

64. The court cited Hunter v. Erickson, 393 U.S. 385 (1969); Loving v. Virgmia, 388 U.S. 1 (1967); and McLaughlin v. Florida, 379 U.S. 184 (1964).

65. 82 Wash. $2 \mathrm{~d}$ at $31-32,507$ P.2d at 1181-82. 
compelling state interests: (1) an interest in eradicating the continuing effects of past discrimination by promoting integration and reducing racial imbalance in public education; ${ }^{68}(2)$ an interest in producing a racially balanced student body so that all law students would have a legal education which would prepare them to deal with the societal problems which will confront thein upon graduation; ${ }^{67}$ and (3) an interest in reducing the shortage of minority attorneys in the profession. ${ }^{63}$

As to the necessity of employing preferential admissions to achieve those purposes, the court stated that

racial imbalance in the law school and the legal profession is the evil to be corrected and it can only be corrected by providing legal education to those minority groups which have been previously deprived

... [W]e believe the minority admissions policy of the law school to be the only feasible "plan that promises realistically to work, and promises realistically to work now."

Therefore, it concluded, DeFunis was not denied equal protection of the laws. ${ }^{70}$

An analysis of the Washington Suprene Court's decision must

66. 82 Wash. $2 \mathrm{~d}$ at $33-35,507$ P.2d at 1182,1183 .

67. 82 Wash. $2 \mathrm{~d}$ at 35,507 P.2d at 1183-84.

68. 82 Wash. $2 \mathrm{~d}$ at 35,507 P.2d at 1184 .

69. 82 Wash. $2 \mathrm{~d}$ at $36,507 \mathrm{P} .2 \mathrm{~d}$ at 1184 (citation omitted). The court considered, but rejected the argument that these objectives could be achieved by improving elementary and secondary education of minority students to a point where they could secure adequate representation in law schools on the basis of the same academic criteria as nonminority applicants:

This would be highly desirable, but 18 years have passed since the decision in

Brown v. Board of Education . . . and minority groups are still grossly under-

represented in law schools. If the law school is forbidden from taking af-

firmative action, this underrepresentation may be perpetuated indefinitely. Id.

70. An interesting question is whether DeFunis v. Odegaard is a noot case. Even though the Washington Supreme Court held that DeFunis was properly demed admission, the trial court's injunction, see note 59 supra, was not explicitly removed. DeFunis lias not been dismissed, and he is expected to graduate in June, 1974. Letter from William R. Andersen, Of Counsel for the law school, Sept. 13, 1973. Therefore, a decision from the United States Supreme Court could well be announced after DeFunis has already received his degree. "To adjudicate a cause which no longer exists is a proceeding which [the] Court uniformly has declined to entertain." Sears, Roebuck \& Co. v. Local 419, AFL-CIO, 397 U.S. 655, 657 (1970) (citations omitted).

This issue was not, however, addressed by any of the briefs for appeal or certiorari. See Appellant-Petitioners' Brief for Jurisdiction or Certiorari, Appellee-Respondents' Brief for Dismissal of Appeal or Opposition to Certiorari, Brief for AntiDefamation League of B'nai B'rith as Amicus Curiae, DeFunis v. Odegaard, 82 Wash. 2d 11, 507 P.2d 1169, cert. granted, 42 U.S.L.W. 3300 (U.S. Nov. 19, 1973) (No. 73-235). 
begin with an evaluation of the court's application of the higher standard of equal protection review in a factual context unlike that in which the higher standard devcloped. If that standard was inappropriate, does precedent exist for the application of the lower standard in such a case? Before these questions are answered, it is necessary to discuss a threshold issue which decided the case in the trial court: whether, under the fourteenth amendment, racial classifications are ever permissible.

\section{The Use of Racial Criteria: Is the CONSTITUTION "COLOR-BLIND"?}

The argument, accepted by the DeFunis trial court, that race may never be the basis of a state's classification of persons within its jurisdiction probably finds its inception in the first Justice Harlan's sole dissenting opinion in Plessy that "[o]ur Constitution is colorblind. . . ."71 Implicit in that dissent, lowever, is Justice Harlan's assumption that racial criteria, if permitted, would always be used to keep the black American in a condition of legal and social inferiority. ${ }^{22}$ In context, therefore, Justice Harlan's statement cannot be said to support the color-blindness standard einployed by the DeFunis trial court. That court cited Brown to support its lolding that race could never be used as a criterion for classification by the state; ${ }^{73}$ but the Brown Court, while adopting Justice Harlan's reasoning that legally imposed segregation was a badge of inferiority imposed on black Americans, ${ }^{74}$ made no mention of the color-blindness statement.

Another reason why Brown should not be interpreted as proscribing all racial classifications, and the reason primarily rclied upon by the Washington Supreme Court, arises from the factual distinction betwecn Brown and DeFunis: Brown struck down racial classifications which were being used, and historically always had been used, to discriminate against black Americans. As the Washington Supreme Court concluded, such was not the case in DeFunis:

[Brown] held that invidious racial classifications-i.e., those that stigmatize a racial group with the stamp of inferiority-are unconstitutional

71. 163 U.S. 537,559 (1896). The argument is developed further by additionul language in that dissent:

... I deny that any legislative body or judicial tribunal may have regard to the race of citizens when the civil rights of those citizens [i.e., the right to use public railway accommodations] are involved. ... The law regards man as man, and takes no account of ... his color when his civil rights as guaranteed by the supreme law of the land are involved. Id. at 554-55, 559.

72. See 163 U.S. at $560,562,563$.

73. See note 58 supra and accompanying text.

74. See notes 48-52 supra and accompanying text. 
.... "Preferential admissions do not represent a covert attempt to stigmatize the majority race as inferior; nor is it reasonable to expect that a possible effect . . . will be to stigmatize whites."75

Brown, then, does not require absolute color-blindness as a prerequisite to compliance with the equal protection clause. ${ }^{76}$

Recent cases which construe the Brown opinion support the Washington Supreme Court's holding that racial classifications are not per se invalid. In Green v. County School Board, ${ }^{77}$ the Supreme Court struck down a "freedom of choice" desegregation plan which adopted a racially neutral approach in which no student was assigned or admitted to any school on the basis of race. In essence the Court held that Brown required more than a cessation of segregation; it required affirmative integration as well. To achieve the conversion from a dual, segregated school system to a unitary school system, the school board was charged with an affirmative duty to reduce racial imbalance. ${ }^{78}$

The Supreme Court elaborated on its call for affirmative action from school boards in Swann v. Charlotte-Mecklenburg Board of Education $^{79}$ and its companion case, North Carolina State Board of Education v. Swann..$^{80}$ In the first case, the Court held that in fashioning a unitary system under the precepts of Green, a school board need not be "color-blind" but may consider race as a valid criterion.

As we said in Green, a school authority's remedial plan or a district court's remedial decree is to be judged by its effectiveness. Awareness of the racial composition of the whole school system is likely to be a useful starting poimt in shaping a remedy to correct past constitutional violations. $^{81}$

75. 82 Wash. 2d at 27, 507 P.2d at 1179 (emphasis added), quoting O'Neil, supra note 1 , at 713 .

76. The exact meaning of the Brown decision has been the subject of extensive debate but most commentators agree that, while Brown did not sanction the use of ameliorative racial classifications, neither did it adopt the view that racial classifications were per se invalid. See, e.g., Fiss, Racial Imbalance in the Public Schools: The Constitutional Concepts, 78 HARv. L. REv. 564, 594 (1965); Goldman, Benign Racial Classifications: A Constitutional Dilemma, 35 U. CrNN. L. REv. 349, 362 (1966); Wechsler, Toward Neutral Principles of Constitutional Law, 73 HARv. L. Rev. 1, 32 (1959); Comment, Alternative Schools for Minority Students: The Constitution, The Civil Rights Act and the Berkeley Experiment, 61 CALIF. L. REv. 858, 870-73 (1973).

77. 391 U.S. 430 (1968).

78. The "freedom of choice" plan was not unconstitutional per se, but it was not as effective as other available methods of abolishing the segregated school system. $I d$. at $440-41$.

79. 402 U.S. 1 (1971). Swann upheld the power of the federal district court to prescribe wide-scale intra-district busing to achieve a unitary, imtegrated school system.

80. 402 U.S. 43 (1971).

81. 402 U.S. at 25. 
In the companion case, the Supreme Court invalidated a North Carolina statute which prohibited involuntary busing of students in order to create racial balance. ${ }^{82}$ On its face the law absolutely forbade the use of racial classifications in student assignment. The Court concluded, however, that although

the statute exploits an apparently neutral form to control school assignment plans by directing that they be "color blind" [,] that requirement ... would render illusory the promise of Brown v. Board of Education .... . Just as the race of students must be considered in determining whether a constitutional violation has occurred, so also must race be considered in formulating a remedy. ${ }^{83}$

The most recent affirmation of the Court's rejection of the colorblindness standard may be found in Keyes v. School District No. $19^{84}$ the Denver school desegregation case. There the majority, in answer to a point made by Justice Rehnquist in his dissent, ${ }^{85}$ stated that Green was the controlling case, not Brown, and that the school could not

82. N.C. GeN. Stat. $\$ \$ 115-176.1$ (Supp. 1971), known as the Anti-Busing Law, read in pertinent part:

No student shall be assigned or compelled to attend any school on account of race, creed, color or national origin, or for the purpose of creating a balance or ratio of race, rehigion, or national origins. Involuntary busing of students in contravention of this article is prohibited, and public funds shall not be used for any such busing.

83. 402 U.S. at 45-46. Professor Alexander Bickel, in the amicus brief submitted on behalf of B'nai B'rith, see note 4 supra, argued that Green and Swann cannot be construed to sanction racial classifications in a preferential admissions context. He contended that these cases allowed the use of racial criteria only because it was necessary to irradicate the effects of state-imposed segregation, and that there was no allcgation or history of state-imposed segregation in DeFunis. See Brief for Anti-Defamation League, supra note 70, at 12-14. This argument, however, overlooks the underlying purpose of Green, Swann, and similar desegregation cases: to bring public education into line with the basic precepts of the fourteenth amendment. Since this is exactly the purpose of the law school's minority admissions program, see notes 106-11 infra and accompanying text, Green and Swann are valid precedent for holding that ameliorative racial classifications are not per se invalid.

84. 93 S. Ct. 2686 (1973). Keyes involved a situation in which the school board, through various devices, had engaged in segregative practices aimed at minority students in one section of the school district. In the inner city, where schools were predominantly attended by minority students, the school board had not been shown to have engaged in discriminatory practices, and the segregation that existed was apparently of a de facto nature. The Supreme Court held that the existence of identifiably minority schools, coupled with the history of discrimination in other parts of the district, gave rise to a presumption that the inner city segregation was de jure. The burden was then on the school board "to adduce proof sufficient to support a finding that segregative intent was not among the factors that motivated their actions" involving the inner city schools. Id. at 2698.

85. Id. at 2722. Mr. Justice Rehnquist distinguished the Keyes situation from that presented in Green on the ground that in Green the school board had for years rigidly excluded Negroes from white schools. 
remain racially neutral in fulfilling its duty to establish a unitary, desegregated school system. ${ }^{86}$

It may be concluded, therefore, that, regardless of the original meaning of Brown, ${ }^{87}$ the United States Supreme Court has decided that racial classifications are not per se violative of the equal protection clause of the fourteenth ainendment. ${ }^{88}$ The Washington Supreme Court was therefore correct in overturning the simplistic decision of the trial court in DeF unis. ${ }^{89}$

86. Id. at 2693-94 n.11. The manner in which Mr. Justice Rehnquist presented his argument, see $i d$. at 2722 , and the manner in which it was rejected by the majority indicates the waning utility of Brown in contemporary desegregation situations. Brown has now taken its rightful place as the cornerstone of an increasingly complex constitutional edifice built by twenty years of judicial construction.

87. See notes 73-76 supra and accompanying text.

88. The federal courts of appeals in over half the judicial circuits have arrived at the same conclusion in a variety of factual contexts. See Carter v. Gallagher, 452 F.2d 315, 331 (8th Cir. 1971), cert. denied, 406 U.S. 950 (1972) (it is within the equitable power of a federal district court to set minority-majority hiring ratios as a means of eliminating the effects of past invidious discrimination); Porcelli v. Titus, 431 F.2d 1254, 1257 (3d Cir. 1970), cert. denied, 402 U.S. 944 (1971) (appointment of school adininistrators "based partly on considerations of color, when color is not used per se, and in furtherance of a proper governmental objective, is not necessarily a violation of the Fourteenth Amendment"); Norwalk CORE v. Norwalk Redevelopinent Agency, 395 F.2d 920, 932 (2d Cir. 1968) (although the Constitution usually forbids racial classification, "where it is drawn for the purpose of achieving equality [in housing relocation] it will be allowed . ..."); Offerman v. Nitkowski, 378 F.2d 22, 24 (2d Cir. 1967) (school board may adopt racial criteria in implementing a voluntary plan of eliminating de facto segregation. "What is prohibited is use of race as a basis for unequal treatinent"); Brooks v. Beto, 366 F.2d 1, 24 (5th Cir. 1966), cert. denied, 386 U.S. 975 (1967) (race may be considered in selection of juries if the effect is to foster the eradication of former discrimination); Wanner v. County School Bd., 357 F.2d 452, 454 (4th Cir. 1966) (when a school board voluntarily undertakes a desegregation plan, its efforts are not to be frustrated on the ground that race is not a permissible consideration because "[t]his is not the "consideration of race' which the Constitution discountenances"); Springfield School Comm. v. Barksdale, 348 F.2d 261, 266 (1st Cir. 1965) (a school committee may implement a voluntary desegregation plan using racial criteria because that action "does not concern race except insofar as race correlates with proven deprivation of educational opportunity"). Cf. Contractors Ass'n v. Secretary of Labor, 442 F.2d 159 (3d Cir.), cert. denied, 404 U.S. 854 (1971).

89. Although the trial court and the Washington Suprente Court concentrated on Brown and its progeny regarding the validity of race as a criterion, the other hine of race cases, those involved in the developnent of the strict standard of review, also support the conclusion that racial classifications are not per se invalid: in two of these cases concurring Justiccs maintained that the racial classifications involved were per se invalid, but the nuajority never adopted this view. Loving v. Virginia, 388 U.S. 1, 13 (1967) (Stewart, J., concurring); McLaughlin v. Florida, 379 U.S. 184, 198 (1964) (Stewart \& Douglas, J.J., concurring). 


\section{The Higher Standard of Review: ARe Ameltorative CLASSIFICATIONS SUSPECT?}

In determining the appropriate standard of review to apply to the law school's minority admissions program, the Washington Supreme Court relied mainly on three cases ${ }^{00}$ which had stated that racial classifications were suspect, and should consequently receive strict scrutiny. The defendants had suggested that the lower, rational basis standard should apply because the racial classifications made in $D e$ Funis, unlike those attacked in the cases which originally declared race a suspect classification, were not for the purpose of stignatizing minority groups, but rather for the purpose of benefiting those persons still suffering the effects of a long history of racial discrimination. ${ }^{01}$ The court summarily dismissed this argument, however, observing that the racial classifications drawn by the law school were "certainly not benign with respect to nonminority students" denied admission. ${ }^{92}$ While the Washington Supreme Court was correct in reading the cited decisions to mean that race had always been considered a suspect criterion, it failed to point out that all of those cases were decided agamst a background of imvidious discrinination against minority groups. This is not to say that the entire body of suspect-classification cases should be summarily distinguished on the facts, but the factual difference in DeFunis certainly requires a threshold inquiry to deterinine whether the factors which have made racial classifications suspect in the past are characteristic of annehorative racial classifications. If not, the Court should not blindly follow precedent and apply the higher standard of review in a situation where application of that standard inay actually thwart the purposes for which it was developed.

The inquiry can be broken down into two parts: (1) Why has the Supreme Court labeled some classifications "suspect" and applied to them the higher standard of review? (2) Do the reasons for denommating some classifications "suspect" support the application of that label to racial classifications used in a preferential admissions program?

90. Hunter v. Erickson, 393 U.S. 385 (1969); Loving v. Virginia, 388 U.S. 1 (1967); McLaughlin v. Florida, 379 U.S. 184 (1964).

91. See DeFunis v. Odegaard, 82 Wash. 2d at 32, 507 P.2d at 1182.

92. Id. The court would have made a much clearer statement of its reasoning if it had phrased its observation in terms of "preferential treatment" or "ameliorative classification," instead of "benign classification." See note 6 supra. As it stands, however, the court immediately foreclosed a line of inquiry into the true nature of an ameliorative racial classification, and thereby failed adequately to justify its refusal to apply the rational-basis standard of review. 


\section{Suspect Classifications: Parameters and Definitions}

One explanation for the Supreme Court's decision that some criteria are constitutionally suspect when used by the state to classify persons under its jurisdiction emerges from language the Court has used in various cases over the past thirty years. This recurring theme is that a criterion is suspect if it is irrelevant to any legitimate state objective $^{93}$ or to the ability of an individual to perform in and contribute to society..$^{94}$ The underlying argument is that if a criterion is actually irrelevant to a pernissible state objective use of such a criterion will result in purely arbitrary classifications. Not every arbitrary classification is suspect; the Court has commonly employed the rational-basis standard to evaluate non-suspect but arbitrary classifications. ${ }^{95}$ Rather, the Court has been concerned with those arbitrary classifications which historically have repeatedly been drawn because of some irrelevant but easily recognizable trait such as black skim.

The use of race as a criterion has been a major concern of the Supreme Court if only because that criterion has been used over and over by the states in fashioning classifications which stigmatized racial minorities, relegating them to a position of legal and social inferiority and isolating them from the political and social decision-making processes which are supposed to consider their rights and needs. ${ }^{96}$ This judicial concern is evidenced by the oft-repeated statement that

[t]he clear and central purpose of the Fourteenth Amendment was to eliminate all official state sources of invidious racial discrimination $\ldots .^{97}$

Racial classifications are especially abhorrent because they are based on inherent, immutable personal traits which, though genetically no accident, are completely beyond the control of the stigniatized group. ${ }^{98}$

Against this historical background of imvidious discrimination against racial minorities, the Court developed a standard of review which made it almost impossible for the state to justify the use of

93. See, e.g., McLaughlin v. Florida, 379 U.S. 184, 191-92 (1964); Hirabayashi v. United States, 320 U.S. 81, 100-01 (1943).

94. See Frontiero v. Richardson, 411 U.S. 677, 686 (1973), citing Developments at $1173-74$.

95. See, e.g., Reed v. Reed, 404 U.S. 71 (1971).

96. For a legal historian's view of the efforts of states to stigmatize and isolate black Americans see Black, The Lawfulness of the Segregation Decisions, 69 Yale L.J. 421 (1960).

97. E.g., Palner v. Thomıson, 403 U.S. 217, 236 (1971) (Douglas, J., dissenting); Loving v. Virginia, 388 U.S. 1, 10 (1967) (enphasis supplied).

98. See Frontiero v. Richardson, 411 U.S. 677, 686 (1973); Developments at 1126-27. 
a racial classification. The first suggestion that a higher standard of review might be needed appeared in a footnote written by Justice Stone speaking for a plurality of the Court in United States $v$. Carolene Products $\mathrm{Co}^{99}$ Justice Stone suggested that some types of state legislation might, under the fourteenth amendment, be denied the usual presumption of constitutional validity, and might be subjected to "more exacting judicial scrutiny" than other types of legislation. Included in the types of legislation which might be more closely examined were statutes directed at racial or national minorities: ${ }^{100}$

[P]rejudice against discrete and insular minorities may be a special condition, which tends seriously to curtail the operation of those political processes ordinarily to be relied upon to protect minorities, and which may call for a correspondingly more searching judicial inquiry. ${ }^{101}$

This footnote did not receive the support of a majority of the Court, and it was not expressly relied on in subsequent racial discrimination cases; but the concepts announced in that footnote have been continually expressed in later cases which sought to insure that the efforts of minority groups to secure fair representation in the decision-making process were protected by a higher standard of review. ${ }^{102}$ The contin-

99. 304 U.S. 144, 152-53 n.4 (1938).

100. Id. at 153 n.4. Other types of legislation were restrictions on the right to vote, restraints upon dissemination of information, interferences with political organizations, prohibitions of peaceable assembly, and statutes directed at particular religious minorities. Id. at 152-53 n.4.

101. Id. at 153 n.4.

102. See Hadnott v. Amos, 394 U.S. 358, 361-64 (1969) (enforcement of election filing statute which excluded Negroes, but not similarly situated whites, from candidacy violated fourteenth amendment); Hunter v. Erickson, 393 U.S. 385, 391-93 (1969) (city charter aunendment violated the fourteenth amendment because it made it moro difficult for minorities to enact legislation in their behalf); Louisiana v. United States, 380 U.S. 145, 151-53 (1965) (state could not enforce a literacy clause in a manner which arbitrarily deprived Negroes of the right to vote); Virginia Bd. of Elections v. Hamm, 379 U.S. 19, aff'g per curiam, 230 F. Supp. 156 (E.D. Va. 1964) (affirmance of lower court opinion which hold that the compulsory listing of qualified voters by their race tended to separate individuals by race alone and was therefore violative of the fourteenth amendment); Anderson v. Martin, 375 U.S. 399, 401-04 (1964) (compulsory designation by Louisiana of the race of the candidate on the ballot acted to encourage racial prejudice and therefore violated the fourteenth amendment). Cf. Loving v. Virginia, 388 U.S. 1, 11-12 (1967) (anti-miscegenation statuto violated fourteenth amendment because it sought to perpetuato white supremacy); Bates v. City of Little Rock, 361 U.S. 516, 522-27 (1960) (compulsory disclosure of NAACP membership lists violated fourteenth amendment due process because it violated Negroes' right to associate for the purpose of advancing ideas and airing grievances); NAACP v. Alabama, 357 U.S. 449, 460 (1958) (right of Negroes to associato must be held inviolate because effective advocacy of public and privato points of view is a gnarantee of the fourteenth amendment due process clause). 
uing validity of Justice Stone's footnote is evidenced in a recent line of cases involving state classifications based on alienage. There the Court has relied in part on that footnote for its position that aliens, as a "discrete and insular" minority, warrant "heightened judicial solicitude" so that their riglits might be fully protected. ${ }^{103}$

From this background it is possible to suggest a definition of "suspect classification": it is one which is based on a readily identifiable, usually immutable characteristic, and one which the Court suspects is being used by a state against a politically inipotent minority group to keep members of this group in an inferior position and to isolate them from the political process. ${ }^{104}$ If a state classification has one of these purposes or effects, the Court will apply the higher standard of review. ${ }^{105}$

\section{Ameliorative Racial Classifications: Do They Fit?}

The remaining question is whether the racial classification em-

It is interesting to note that the Court has concurrently sought to insure proper minority representation in the criminal process. See, e.g., Alexander v. Louisiana, 405 U.S. 625, 628-32 (1972) (state bore heavy burden of showing that progressive elimination of Negroes during grand jury selection process was not caused by invidious discrimination).

103. In re Griffiths, $93 \mathrm{~S}$. Ct. 2851, 2854-55 (1973); Sugarinan v. Dougall, 93 S. Ct. 2842, 2847 (1973); Graham v. Richardson, 403 U.S. 365, 372 (1971).

104. It has been strongly argued in recent years that criteria other than race, alienage and national origin should be considered "suspect." In San Antonio Independent School Dist. v. Rodriguez, 411 U.S. 1 (1973), the lower court had held that wealth was a suspect classification. 337 F. Supp. 280, 282-83 (W.D. Tex. 1971). The Supreme Court declined to hold specifically that wealth was not a suspect classification, but held that any discrimination in the factual situations before it had not been based on wealth. The issue remains, therefore, whether the Court will ever designate wealth a suspect classification. In some respects, wealth fits the definition here suggested: the poor are usually a politically-impotent group and are generally excluded from the mainstream of political life. On the other hand, poverty is not, theoretically, an immutable characteristic. On the contrary, basic to our American ideology is the concept of upward economic mobility.

It has also been argued that sex is a suspect criterion, and the arguments have convinced four members of the Supreme Court. Frontiero v. Richardson, 411 U.S. 677, 682-88 (1973) (Brennan, J., for the plurality). Four other Justices in that case rehed on Reed v. Reed, 404 U.S. 71 (1971), which had struck down a classification based on sex without holding that sex was a suspect classification. Sex, like wealth, also has both suspect and non-suspect characteristics under the suggested definition: sex is certainly an immutable trait, and women as a class have traditionally been poorly represented in the political process; however, women do not presently constitute a minority.

105. Ancillary support for the proposition that only invidiously discriminatory racial classifications are suspect may be found in a recent Suprene Court footnote explaining why the higher standard of review was not employed in that case. See Dandridge v. Williams, 397 U.S. 471, 485 n.17 (1970). 
ployed in the DeFunis case should be considered suspect, and consequently subjected to the higher standard of review. This inquiry might begin by asking whether the law school's ameliorative racial classification is relevant either to any legitimate state objective or to the abilities of the persons so classified to function in the law scliool environment. If the classification is not relevant, it is purely arbitrary and might be considered constitutionally suspect. The obvious answer is that the law school's classification is clearly relevant to a valid state purpose. The purpose of the racial classification in DeFunis is to reduce racial imbalance in the law school and in the legal profession. That the reduction of racial imbalance is a permissible state objective is reflected in the lower court decisions upholding affirmative state action plans ${ }^{106}$ and in earlier Supreme Court decisions which explicitly or implicitly recognized the value of educational intercourse among the races. ${ }^{107}$ The relevance of the racial classification is also apparent: if the racial imbalance is to be reduced, the law school must be aware of, and must consider, the race of each applicant. ${ }^{108}$

The second part of the inquiry must ask whether the state, in using the racial classification, is attempting to place members of minority races in positions of legal or social inferiority or to keep them out of the political process. A strong argument can be made that the law school's objectives in using the classification are exactly the reverse. The purpose of the admissions program is to aid disadvantaged minority applicants in becoming members of a highly respected profession, and the immediate effect of the racial classification is to place minority applicants in an admissions posture superior to some white applicants. While it lias been suggested that singling out minority members for any special treatment may have a stigmatizing effect, ${ }^{109}$ the basic premise of Brown and its progeny was that a reduction of racial imbalance in public educational institutions will reduce, not increase, the stigmatization of minorities. ${ }^{110}$ Further, rather than insulating minorities from the political process, the law school, in using the racial classification, seeks to increase their ability to participate therein. Lawyers have traditionally been the lead-

106. See note 88 supra.

107. See Brown v. Board of Educ., 347 U.S. 483 (1954); McLaurin v. Oklahoma State Regents, 339 U.S. 637 (1950).

108. This is the same type of reasoning adopted by the Court in Swann v. CharlotteMecklenburg Bd. of Educ., 402 U.S. 1 (1971). See note 81 supra and accompanying text.

109. See note 113 infra.

110. See note 50 supra and accompanying text. 
ers in the business and political community, and any racial classification that promises to increase the number of minority lawyers consequently promises to provide greater protection to the rights, and closer attention to the needs, of minorities. ${ }^{111}$

Froin the preceding discussion it is clear that the ameliorative racial classifications used in the law school's admissions process do not have the characteristics which have caused the Supreme Court to denominate racial classifications "suspect" in the past and, therefore, should not be subjected to the higher standard of review. It would be ironic indeed if a standard of review which was developed to lrelp end discrimination agaimst nembers of minority groups were used to ban state practices designed to alleviate the effects of that very discrimination.

If the higher standard of review is inappropriate for application to ameliorative racial classifications, the alternative is the "lower" standard of review, the "rational-basis" test. Several objections have been made to this alternative, but none outweigh the basic lack of logic involved in the application of the higher standard to ameliorative racial classifications.

111. The gross underrepresentation of minorities in law schools, and consequently in the legal profession, is a well-documented fact, and the figures are startling. As of 1968, it was estimated that only 200 law graduates out of 10,000 were black; proportionate representation would have been around 1200 out of 10,000. Gellhorn, The Law Schools and the Negro, 1968 Duke L.J. 1069, 1077. Froin 1965-68 the University of Georgia enrolled only one black law student, and the University of Alabama law school, which had never graduated a Negro, had none. Id. at 1081. Moreover, this phenomenon was not confined to the South: in 1971 Cornell University had only 7 Negro law students out of 460; University of Cincinnati, 7 out of 352; University of Chicago, 14 out of 475; University of Missouri, 1 out of 420; Stanford University, 10 out of 504. ABA-Law STUdent Division, EQual Rights Project REPORT, at 12, 24, 28, 31, 36 (1971). The numbers are increasing due to recently instituted minority recruitment programs, see id. at 68-92, but a recent survey of over 100 law schools showed that for the 1970-71 academic year only about $4.5 \%$ of eurolled law students were meinbers of any minority group. Id.

As of 1971, only 4300 of the 350,000 lawyers in the United States were black. Comment, supra note 58, at 752 n.91. In 1968 only 9 out of almost 1 million Negroes in Mississippi practiced law; only 20 in Alabama; and only 34 out of Georgia's 5500 lawyers were black. Gellhorn, supra, at 1074. As of 1971 only 10 out of 357,000 Negroes in Arkansas, and only 11 out of 789,000 in South Carolina, were lawyers. Comment, supra note 58, at 752 n.91. Through 1968 no American Indian had ever graduated from the law school at the University of Utah, Arizona, or New Mexico, and no Indian was practicing law in the last two states, which had a conibined American Indian population of 135,000. Id. In 1967, Denver, with a 9\% Chicano American population, could count only 10 Chicano lawyers out of its 2000-member bar. Id. at $753 \mathrm{n} .92$. 


\section{APPLICATION OF THE LOWER STANDARD OF REVIEW}

Many arguments have been made which imply that the use of a lenient standard to review amehorative racial classifications would be inappropriate: (1) such classifications offend fundamental notions of individualism by seeking to aid groups instead of individuals, ${ }^{112}$ (2) they promote private color consciousness and further stigmatize those minorities selected for special treatment; ${ }^{113}$ (3) they could be abused to impose more invidious discrimination on minorities; ${ }^{114}$ (4) they discriminate agamst other disadvantaged classes not selected for the group receiving preferential treatment; ${ }^{, 115}$ (5) and they may be used to establish strict racial quotas both cumbersone to administer and unfair to nuany parties involved, both minority and nonminority. ${ }^{110}$ These objections appear to be based on the assumption that the lower standard of review is simply not adequate to insure that preferential treatment programs accoinplish their amehorative objectives while avoiding possible misuses and pitfalls. Apparently the feeling is that if the Court applies the rational-basis standard, every allegedly amehorative racial classification will summarily be held constitutional.

It is true that for many years the Court's decisions as to the applicable standard was dispositive of the case, because, if the lower standard was used, a rational relation between the classification and sonie permissible state purpose was always found. But the Court has recently begun to examine classifications inore carefully under the lower standard to see whether the required rational relationship really exists. $^{117}$ No longer is the presumption of validity dispositive of the case. Under the lower standard, the Court would now make a reasoned inquiry into whether there is a permissible state purpose, and whether the ameliorative racial classification is reasonably related to the acconplishment of that purpose.

112. Developments at 1111-12.

113. See Kaplan, supra note 5, at 376, 378, 379-80; O'Neil, supra note 1, at 710; Summers, Preferential Admissions: An Unreal Solution to a Real Problem, 1970 U. ToL. L. Rev. 377, 395-97; Vieira, Racial Imbalance, Black Separatism, and Permissible Classification by Race, 67 MrCH. L. REv. 1553, 1614-15 (1969); Developments at 1112-13.

114. See O'Neil, supra note 1, at 710; Vieira, supra note 113, at 1611-12; Developments at 1115-16.

115. Sce Kaplan, supra note 5 , at 375,377 ; Vieira, supra note 113 , at 1613-15; Developments at 1119-20.

116. See Kaplan, supra note 5, at 400-04; Vieira, supra note 113, at 1612; Developments at 1117-19.

117. See note 45 supra. 
Lingering doubts about the amenability of ameliorative racial classifications to rational-basis review are allayed by the fact that the Supreine Court has very recently used a rational-basis approach to strike down state rules based on alienage, which, like race, has traditionally been considered suspect. In Sugarman v. Dougall, ${ }^{118}$ the Court, while purporting to use the higher standard of review, ${ }^{119}$ struck down a section of the New York Civil Service Law based on alienage ${ }^{120}$ because the classification so drawn was too imprecisely related to a valid state interest. ${ }^{121}$ Again, in In re Griffiths ${ }^{122}$ the Court cited the state's obligation under the strict scrutiny standard, ${ }^{123}$ but then held that the state bar examiners' rule precluding aliens from the practice of law was not rationally related to the achievement of an admittedly substantial state objective. ${ }^{124}$

Under the rational-basis standard as it is now employed, the law school's preferential admissions prograin would be approved. The purpose is certainly permissible. ${ }^{125}$ The harder question is whether a preferential admissions program is rationally related to that purpose in light of the available alternatives, such as improving the quality of elementary and secondary school so that minority meinbers might coinpete for law school admissions under traditional standards, or establishing preferential admissions programs in undergraduate schools only. The Washington Supreme Court rejected the first alternative as unreasonable because almost twenty years have passed since Brown ordered that black children be allowed to attend white schools, and minorities are still grossly underrepresented in law schools. ${ }^{126}$ The

118. 93 S. Ct. 2842 (1973).

119. Id. at 2847.

120. Laws of New York, 1939 , ch. $767, \S 1$, provided: "[N] person shall be eligible for appointment for any position in the competitive class unless he is a citizen of the United States." The "competitive class" included all positions for which a competitive examination was given to determine an applicant's relative fitness. Sugarman v. Dougall, 93 S. Ct. at 2846.

121. $93 \mathrm{~S}$. Ct. at 2848. The Court recognized that the state had a valid interest in setting up its own government, and in limiting participation therein to those within the basic couception of a political community. Id.

122. 93 S. Ct. 2851 (1973).

123. Id. at 2854-55.

124. Id. at 2855-56. The Court stated that the state liad a substantial interest in insuring the requisite qualifications for members of the bar.

The willingness of the Court in Sugarman and Griffiths to jumble and mix the elements of the higher and lower standards of review, may signal the Court's continuing dissatisfaction with a rigidly-structured two-tiered standard of review, and the continuing demise of that two-level standard. See Gunther, supra note 45.

125. See notes 110-11 supra, and accompanying text.

126. 82 Wash. $2 d$ at 36,507 P. $2 d$ at 1184. 
second alternative is also unfeasible because the mere increase in minority undergraduates has not by itself significantly increased the number of minority students accepted to law schools. ${ }^{127}$ A preferential admissions program sponsored by the law school would therefore seem to be the best available ineans of accomplishing the permissible state purpose.

\section{CONCLUSION}

The law and practice of race relations is constantly changing; racial classifications are no longer always invidious; states are striving to fulfill the purposes of the fourteenth amendment after more than a century of delay. The Supreme Court should acknowledge these changes by recognizing the difference between the traditional racial classifications which sought to perpetuate Jim Crow, and those hike the University of Washington law school's which seek to lay Jim Crow in his grave. DeFunis v. Odegaard provides the Supreme Court with an excellent opportunity to further refine the definition of "suspect classification" and to announce that not all classifications are suspect. Those who affirmatively seek to erase the effects of past discrimination and thereby achieve the clear purposes of the fourteenth amendment should not be denied their goal through the misapplication of a legal concept which was never intended to apply in such a situation.

127. See Gellhorn, supra note 111, at 1081. Cf. O'Neil, supra note 1, at 721 . 